\title{
Narodziny, rozwój i dezintegracja idei praw fundamentalnych i tradycyjnej konstytucji w zachodniej myśli politycznej od renesansu do oświecenia
}

\section{WPROWADZENIE}

Każdy student prawa lub politologii w pierwszym skojarzeniu definiuje konstytucję jako ustawę zasadniczą i dopiero po chwili przypomina sobie, że istnieje jeszcze specyficzny wypadek angielski braku spisanej konstytucji. Czasami także wie, że takie państwa jak Hiszpania epoki Franco czy współczesny Izrael mają tzw. konstytucję rozproszoną, czyli kilka-kilkanaście komplementarnych aktów prawnych składających się na konstytucję. W tekście tym zostanie przedstawiona idea praw fundamentalnych i przednowoczesnych konstytucji. Pod tym pierwszym pojęciem rozumiemy te formuły prawne, które zostały jasno i dobitnie sprecyzowane, pod drugim - zasady tradycyjnego ustroju, cieszące się powszechnym szacunkiem, acz ewoluujące wraz z tradycją prawną.

Czy istnieją przednowoczesne konstytucje, wcześniejsze niż amerykańska (1787) i Konstytucja 3 Maja (1791)? Oczywiście. Niemiecki filozof Samuel Pufendorf w 1672 r. definiował suwerenność następująco:

Gdy mówimy, że władca posiada władzę absolutną, rozumiemy przez to, iż posiada uprawnienie do rządzenia państwem tak, jak uważa zależnie od bieżącej sytuacji, nie musząc się nikogo radzić ani słuchać określonych stałych i wiecznych reguł, od których nie mógłby prawowicie się uwolnić ${ }^{\text {. }}$

${ }^{1}$ S. Pufendorf, De oficio hominis et civis juxta legem naturalem libri duo, Lund 1673, ks. II, rozdz. IX, pkt 6 (przywoływane fragmenty w przekładzie własnym). 
Ludzie jednakże - przekonuje dalej - zwykle nie chcą oddać królom władzy tak nieograniczonej, obawiając się tyranii i nadużyć:

Dlatego [...] wiele ludów uznało za stosowne ograniczyć w różny sposób wykonywanie władzy suwerennej. To ograniczenie władzy suwerena polega na tym, że lud - aby skutecznie powstrzymać króla przed działaniem na niekorzyść państwa - wymaga odeń przysięgi przy okazji wyniesienia na tron, iż będzie stosował się do określonych reguł, czyli do praw fundamentalnych, w wykonywaniu powierzonej mu suwerenności, a w sytuacjach o niezwykłej wadze, które nie zostały przez nie uregulowane, nie zrobi nic bez udziału i zgody ludu lub jego przedstawicieli, których będzie musiał zwołać jako zgromadzenie².

Ustrój z władzą suwerenną ograniczoną przez prawa fundamentalne Pufendorf bez wahania nazywa „konstytucją””. Podobnie, dziwiąc się uchwaleniu przez francuskie rewolucyjne Zgromadzenie Narodowe konstytucji w 1791 r., Joseph de Maistre pisze, że nie rozumie rewolucjonistów twierdzących, iż przedrewolucyjna Francja nie posiadała konstytucji, rozumiejąc przez to spisaną na papierze ustawę zasadniczą. Przecież każde państwo - powiada tradycjonalista sabaudzki - posiada konstytucję polityczną, utożsamianą przezeń z tradycyjnym dlań ustrojem ${ }^{4}$.

Celem tego tekstu jest opisanie narodzin, rozwoju i zmierzchu przednowoczesnego konstytucjonalizmu, gdy konstytucji nie rozumiano jeszcze jako spisanej i uroczyście uchwalonej, przy specjalnej procedurze, ustawy zasadniczej. Konstytucjonalizm przednowoczesny pojmujemy jako owe prawa fundamentalne i tradycyjne instytucje, o których pisał Pufendorf, będące synonimem ustroju państwa ${ }^{5}$. Chodzi więc nie tylko o deskrypcję przednowoczesnego konstytucjonalizmu i przedstawienie filozofii politycznej, do której się on odwołuje, lecz także o pokazanie przyczyn upadku tej koncepcji, co doprowadziło Europę do fali rewolucji ciągnących się od 1789 r. i zastąpienia praw fundamentalnych przez nowoczesne ustawy zasadnicze.

\section{NARODZINY I ISTOTA KONSTYTUCJI ORAZ PRAW FUNDAMENTALNYCH}

Pojęcia konstytucji i ustroju państwa kojarzą się nieodparcie z prawem publicznym. Bez niego nie istnieje państwo w naszym rozumieniu tego słowa, a jedynie niewyraźny podmiot oparty na prawie prywatnym, czyli na systemie dwustronnych

${ }^{2}$ Ibidem, ks. II, rozdz. IX, pkt 7.

${ }^{3}$ Ibidem, ks. II, rozdz. VIII, pkt 10.

${ }^{4}$ J. de Maistre, Considérations sur la France, Paris 1936 [1796], s. 82, 96-97. Szerzej na temat teorii konstytucjonalizmu tego pisarza: A. Wielomski, Od grzechu do apokatastasis. Historiozofia Josepha de Maistre'a, Lublin 1999, s. 290-297.

${ }^{5}$ F. Bluche, L'Ancien Régime. Institutions et société, Paris 1993, s. 28-32; idem, Constitution [w:] idem, Dictionnaire du Grand Siècle, Paris 2005, s. 395A. 
umów. Dlatego trudno mówić o państwie w świecie feudalnym, opierającym się na umowach dwustronnych wasal-senior, gdzie całe posiadane terytorium, wraz z zamieszkującymi je ludźmi, traktowane jest jako własność prywatna, którą można sprzedać, zapisać w testamencie, oddać w wieczyste użytkowanie (tym jest przecież w istocie umowa lenna) lub podzielić między synów, co prowadzi do rozbicia dzielnicowego. To świat, gdzie suzeren jest teoretycznie właścicielem wszystkich i wszystkiego (własność zwierzchnia), a gdzie w rzeczywistości nie podlega mu bezpośrednio nikt i nic (lennicy mają własność użytkową), poza jego domeną prywatną, zwykle niewielką, którą zarządza bezpośrednio i której jest rzeczywistym właścicielem ${ }^{6}$. Sytuację komplikuje dodatkowo zasada, że „wasal mojego wasala nie jest moim wasalem", która nie obowiązuje jedynie w państwach normańskich, a także roszczenia do zwierzchności uniwersalnej, czyli nad monarchami terytorialnymi, ze strony cesarzy bizantyjskiego i zachodniego (od 800 r.), a potem także, w wyniku reformy gregoriańskiej, biskupa Rzymu (od końca XI w.).

O konstytucji możemy mówić dopiero wraz z odkryciem w Europie prawa rzymskiego publicznego pod koniec średniowiecza ${ }^{7}$, gdy stosunki panowania i posłuszeństwa zaczynają wynikać z zasad ogólnych, a nie z prywatnych umów dwustronnych. Charakterystyczne, że mediewalna łacina nie zna podstawowych pojęć politycznych: ani państwa, ani jego atrybutu, czyli suwerenności. Dlatego w późnym średniowieczu, w XIII-XIV w., pojawia się pojęcie Korony Królestwa (Corona Regni), które uznaje się za pierwszą próbę nazwania nowo powstającego podmiotu prawa publicznego, a mianowicie państwa. Korona Królestwa to pojęcie pochodzące z prawa kanonicznego, ponieważ wielcy średniowieczni kanoniści przez stulecia głowili się nad ewentualnym przypadkiem papieża-heretyka (papa hereticus), aby ostatecznie, odwołując się do prawa rzymskiego, rozdzielić urząd papieski (sedes) od zasiadającego na nim człowieka (sedens). Rozdzielenie papieża-urzędu od papieża-osoby pozwalało uznać ewentualne herezje ogłoszone przez biskupa Rzymu za poglądy osoby, a nie urzędu, a tym samym odróżnić urząd, który nie może zbłądzić, od błądzącego tzw. doktora prywatnego. To zaś dawało soborowi lub kardynałom ewentualne prawo do depozycji papieża-heretyka w imię obrony papieża-urzędu'

Rozróżnienie sedes-sedens legiści wykorzystali na rzecz rozdzielenia instytucji państwa, jako bytu abstrakcyjnego, od osoby władcy. W pojęciu Korony Królestwa

${ }^{6}$ O. von Gierke, Rechtsgeschichte der deutschen Genossenschaft, t. I, Berlin 1868, s. 508-514; J. Ellul, Histoire des institutions, t. III: Le Moyen Age, Paris 1976, s. 39-53; M. Bloch, Społeczeństwo feudalne, Warszawa 1981, s. 251-275.

7 P. Stein, Roman Law in European History, Cambridge 1999, s. 38-70; M. Rainer, Das Römische Recht in Europa. Von Justinian zum BGB, Wien 2012, s. 74-122.

${ }^{8}$ E. Kantorowicz, Dwa ciata króla. Studium ze średniowiecznej teologii politycznej, Warszawa 2007, s. 275. 
zawiera się przekonanie, że państwo można oddzielić od osoby nim rządzącej. Czym innym jest skarb państwa, a czym innym prywatna sakiewka monarchy; czym innym są królewszczyzny, a czym innym prywatne posiadłości króla. W skład Korony Królestwa wchodziły granice państwa, którego władca nie może już dzielić między synów; wysokość podatków; prawa i obowiązki władzy i stanów etc. ${ }^{9}$ Wszystko to pozwalało w miarę precyzyjnie oddzielić króla rządzącego sprawiedliwie, a więc prawowicie, od tyrana. Ten ostatni to już nie tylko uzurpator, który w bezprawny sposób zdobył koronę, ale także ten, który ciesząc się prawowitością uzyskania władzy, rządzi w sposób arbitralny i okrutny (rex tyrannus). Król-tyran to napastnik, bandyta, który nastaje na prawa Korony Królestwa, gwałci je, nadużywa pieniędzy państwowych dla celów prywatnych, łamie prawa stanów i nastaje na pozycję Kościoła.

Pojęcie króla-tyrana wprowadzają do mediewalnego języka teologiczno-politycznego gregorianie przy okazji sporu o inwestyturę ${ }^{10}$, a całościowo opracowuje je jeden z nich, a mianowicie Jan z Salisbury ${ }^{11}$. Kościelne źródło pojęcia powoduje, że pierwotnie tyran to ten, kto nastaje na własność lub autonomię Kościoła. Dopiero św. Tomasz z Akwinu definiuje tyranię szerzej, jako złe rządy, i pozwala na obalenie tyrana, dowodząc, że nie narusza to zasady św. Pawła, iż wszelka władza pochodzi od Boga, gdyż mówiąc o władzy, ten budowniczy chrześcijaństwa miał mieć na myśli władzę-instytucję, a tyran-osoba ją właśnie bezcześci ${ }^{12}$. Podobnie obalić można króla gnuśnego (rex inutilis), który nadużywa władzy, nie interesując się sprawami własnego państwa i dopuszczając do tyranii silnych nad słabymi ${ }^{13}$. Wraz ze zwycięstwem gregorianizmu upowszechniła się idea, że rolę tego swoistego sądu konstytucyjnego - który ocenia, czy dany władca jest tyranem i wolno go obalić - jest biskup Rzymu. Papież ekskomunikuje i deponuje władcę-tyrana. Zostało to szczegółowo opisane w dekretałach Innocentego III ${ }^{14}$.

W tym czasie myśl świecka - mam tu na myśli takich pisarzy politycznych jak Manegold z Lautenbach, Rupert z Deutz i Gehorch z Reichersbergu - bardziej

9 J. Baszkiewicz, Myśl polityczna wieków średnich, Poznań 1998, s. 124-129; M. Artola, La Monarchia de España, Madrid 1999, s. 53-66; J. Dąbrowski, Korona Królestwa Polskiego w XIV wieku. Studium z dziejów rozwoju polskiej monarchii stanowej, Kraków 2010.

${ }^{10}$ M. Pacaut, La Théocratie. L'Eglise et le pouvoir au Moyen Age, Paris 1957, s. 88-89; H.-X. Arquillière, L'Augustinisme politique. Essai sur la formation des théories politiques du Moyen-Age, Paris 1972, s. 63-67.

${ }^{11}$ Jan z Salisbury, Policraticus albo o paplaninie dworaków i przekazach filozofów, Lublin 2008, ks. III, rozdz. 15; ks. IV, rozdz. 1-2; ks. VIII, rozdz. 18.

${ }_{12}$ Tomasz z Akwinu, Wykład Listu do Rzymian, Poznań 1987, pkt 1022 i n.

${ }_{13}$ E.M. Peters, Rex inutilis. Sancho II of Portugal and thirteenth century Deposition Theory, „Studia Gratiana” 1967, nr 14, s. 255-305; idem, The Shadow King. Rex Inutilis im Medieval Law and Literature, London 1970, s. 135-169.

${ }^{14}$ Szerzej: A. Wielomski, Teokracja papieska 1073-1378. Myśl polityczna papieży, papalistów i ich przeciwników, Warszawa 2011, s. 220-229. 
akcentowała tyraniczność władzy, gdy ta nastaje nie tylko na Kościół, jego autonomię i majątek, ale także na prawa stanów, życie i mienie poddanych (grzechy: superbia, rapina, perfidia, homicidia). W czasie reformy gregoriańskiej pojawia się w myśli świeckiej rozbudowane pojęcie króla-tyrana, wraz z tezą, że można go prawowicie obalić ${ }^{15}$. Manegold z Lautenbach porównuje władców do „ekonomów” i ,świniopasów”, którym lud ma prawo podziękować za źle wykonywane obowiązki i dokonane nadużycia, odwołując ich ${ }^{16}$.

Myśl ta rozwinęła się pod koniec średniowiecza, gdy ówczesne społeczeństwa europejskie nabrały charakteru stanowego i korporacyjnego, a uprawnienia tych struktur zaczęto traktować jako część ustroju państwa, element należący do Korony Królestwa, a ich naruszenie - jako tyranię ${ }^{17}$. Teoria ta była tak popularna, że wybrzmiała nawet w Kościele, gdzie gallikanie francuscy i koncyliaryści z różnych krain podkreślali prawa biskupów i narodowych kościołów wobec ewentualnej tyranii pontyfikalnej, uznając za konieczne przekierowanie centrum władzy z papieża w ręce regularnie zwoływanych soborów powszechnych. Można rzec, że kierunek ten stanowi refleks korporacyjnej struktury ówczesnego społeczeństwa. Kanoniści-koncyliaryści nie kryli swojej niechęci wobec tyranii i politycznej i eklezjalnej ${ }^{18}$.

Nacisk społeczny sprawił, że powstał obyczaj, iż w trakcie koronacji nowo wybierany lub wstępujący na tron po swoim ojcu władca musiał składać przysięgę lub przysięgi koronacyjne. W polskiej tradycji nazwano je potem mianem artykułów henrykowskich (przysięga podtrzymania praw tradycyjnych) i pacta conventa (przysięgi osobiste elekta). Ta pierwsza przysięga - taka sama dla wszystkich wstępujących na tron - zawierała zobowiązanie do przestrzegania jego praw fundamentalnych i konstytucji.

Prawa fundamentalne i konstytucje z późnego średniowiecza i wczesnej nowożytności (XVI w.) mogą być rozmaite, w zależności od państwa i lokalnej tradycji. I tak w Rzeczypospolitej szlacheckiej w artykułach henrykowskich zapisano wolną elekcję i wyrzeczenie się prób wprowadzenia dziedziczenia tronu, zakaz wypowiadania wojen i prowadzenia ich bez zgody izb, stałe funkcjonowanie rady przybocznej, zwoływanie co dwa lata sejmu. Władca musiał też uznać

${ }^{15}$ H.D. Rauh, Das Bild des Antichrist im Mittelalter. Von Tyconius zum deutschen Symbolismus, Münster 1973, s. 202-204; J. Skomiał, Manegold von Lautenbach. Umowa o władzę wedtug antydialektyka [w:] Z. Rau, M. Chmieliński (red.), Umowa społeczna i jej krytycy w myśli politycznej i prawnej, Warszawa 2010, s. 81-82.

${ }^{16}$ Manegold z Lautenbach, Ad Gebehardum [w:] Libelli de Lite imperatorum et pontificum, t. I, Hannoverae 1891, s. 391-395.

${ }^{17}$ F. Kern, Derechos del Rey y derechos del pueblo, Madrid 1955, s. 124-216; H.G. Walther, Imperiales Königtum, Konziliarismus und Volkssouveränität. Studien zu den Grenzen des Mittelalterlichen Souveränitätsgedankens, München 1976, s. 243-260.

${ }^{18}$ Na przykład J. Almain, Libellus de auctoritate ecclesiae, t. I, Paris 1512, s. 8-9. 
prawo szlachty do zbrojnego oporu, gdyby artykułów nie przestrzegał ${ }^{19}$. Z kolei w Navarrze i w Aragonii wstępujący na tron musiał zaprzysiąc przestrzeganie starych praw samorządowych i wspólnotowych (fueros) $)^{20}$. W Anglii za prawa fundamentalne uchodziła konstytucyjna zasada rządów „króla w parlamencie”, czyli wraz z parlamentem, sformułowana przez wielkich prawników pod koniec średniowiecza (Henry Bracton, John Fortescue) ${ }^{21}$. Inaczej było we Francji, zmierzającej w kierunku absolutyzmu, gdzie za prawa fundamentalne uznawano tylko prawo salickie, dotyczące zasady sukcesji tronu, wykluczające z dziedziczenia kobiety i automatycznie wyznaczające na następcę zmarłego władcy najstarszego z synów, wyjąwszy apostatów i heretyków. Nie chodziło przy tym o niechęć wobec kobiet, ale o motyw nacjonalistyczny - uniemożliwienie ewentualnego przejęcia władzy przez męża królowej będącego cudzoziemcem ${ }^{22}$. Konstytucję utożsamiano zaś z całą tradycją prawno-polityczną.

Słowem, w każdym państwie europejskim prawa fundamentalne i konstytucje są formułowane nie tylko inaczej, ale także często w sposób przeciwstawny. Podczas gdy tradycja polska jest (prawie) republikańska, francuska - absolutystyczna, skupiając się na problemie sukcesji. W punkcie wyjścia zapisane są w nich formuły późnomediewalnej monarchii stanowej, czyli monarchii mieszanej, z ograniczoną w rozmaity sposób władzą monarszą.

\section{POCZĄTEK DEZINTEGRACJI}

\subsection{Przyczyny ideowe i polityczne}

W XVI i XVII w. prawa fundamentalne i tradycyjny konstytucjonalizm atakowane są ze wszystkich stron, a ich obrońcy dwoją się i troją, aby wykazać ich zasadność i prawowitość. Początki dezintegracji tradycyjnego konstytucjonalizmu mają kilka źródeł:

1. Makiawelizm. Niccolò Machiavelliego wielokrotnie przedstawiano jako destruktora klasycznych cnót i tradycyjnego ustroju oraz apologetę politycznej niemoralności, używania w polityce trucizny, sztyletu, podstępu, wiarołomstwa,

19 J. Bardach, B. Leśnodorski, M. Pietrzak, Historia państwa i prawa polskiego, Warszawa 1985, s. 197.

${ }^{20}$ F. Elíaz de Tejada, Antonio Aparisi y Guijarro en la tradición valenciana [w:] Aparisi y Guijarro: las claves de la Tradición Política Española, Sevilla 1973, s. 115-162; L.J. Fortún Pérez de Ciriza, Fueros locales de Navarra, „Príncipe de Viana” 2007, nr 242, s. 865-900.

${ }^{21}$ F. Schulz, Bracton on Kingship, „English Historical Review” 1945, t. LX, s. 136-176; B. Szlachta, Monarchia prawa. Szkice z historii angielskiej myśli politycznej do końca epoki Plantagenetów, Kraków 2001, s. 135-187, 265-318.

${ }_{22}$ G. Coutant de Saisseval, La Légitimité monarchique. Le Droit royal historique, Paris b.r.w., s. 21-56; B. de Chergé, La légimitité, Paris 2005, s. 51-66. 
okrucieństwa etc. ${ }^{23}$ To pewna symplifikacja. W rzeczywistości włoski pisarz odróżnia ustroje ugruntowane przez tradycję od „państw nowych”, rządzonych przez „władcę nowego typu” (principe nuovo), będącego uzurpatorem i tyranem w jednym. Ten ostatni nie jest żadnym księciem - jak zwyczajowo thumaczy się na język polski tytuł jego głównego dzieła - lecz władcą-dyktatorem, który doszedł do władzy nielegalnie, przez zamach stanu lub podbój państwa. Dla umocnienia swojej władzy uzurpator kreuje porządek polityczny i społeczny niemal od nowa. Dla takiego uzurpatora nie ma ani tradycyjnej konstytucji, ani praw stanów, ani kwestii legitymizmu dojścia do władzy. Liczy się tylko przetrwanie i umocnienie władzy. Wszystkie te środki, nazywane od nazwiska Florentczyka mianem makiawelicznych, stanowią zaprzeczenie tradycyjnych praw fundamentalnych każdego istniejącego państwa, gdyż „nowemu księciu” nie chodzi o państwo, a jedynie o zdobycie i ugruntowanie własnej władzy. Stąd potępienie Machiavelliego i jego dzieła ze strony prawie wszystkich pisarzy epoki, którzy za punkt wyjścia swoich rozważań przyjmowali istniejące stosunki, panujące dynastie i legitymizujące ten porządek idee. Jakby przy tym przeoczono, że pisarz ten koncentruje swoją uwagę na uzurpatorze, a nie na władcy prawowitym, czyli na wyjątku, a nie na regule. Uznano go zatem za niszczyciela całego tradycyjnego porządku zamiast za pierwszego socjologa dyktatury.

2. Racja stanu. W literaturze od dawna przyjmuje się, że problematyka racji stanu po raz pierwszy pojawia się u Machiavelliego i Francisco Guicciardiniego ${ }^{24}$. Uważa się, iż ten pierwszy daje nam definicję tego pojęcia, choć sam się nim nie posługuje. Mimo to racja stanu jest u tego ważnego pisarza renesansowego ułomna. Machiavelli w Księciu koncentruje się nie na dobru państwa, lecz na dobru jednostki, która nim rządzi. Racja stanu jest całkowicie podporządkowana jej egoistycznemu interesowi. Państwo jest miejscem i narzędziem do zaspokojenia pragnienia władzy i nie ma celów autonomicznych, nadrzędnych. Makiawelizm stanowi prawny regres w tym sensie, że faktycznie nie ma tu późnośredniowiecznej dystynkcji między personalnym interesem władcy a interesem państwa. Władca i państwa są tym samym, niczym w monarchii patrymonialnej. Skoro nie ma wydzielonych celów, praw i obowiązków państwa, to nie istnieje też dystynkcja prawna między władcą prawowitym a tyranem.

Istotą dojrzałej renesansowej idei racji stanu jest podporządkowanie wszystkiego interesowi państwa, a nie osobie rządzącej. Dobrze widać to w myśli Giovanniego Botero, którego Racja stanu (La ragion di stato, 1589) uznawana jest za

${ }^{23}$ Zob. np. klasyczne rozprawy: L. Strauss, Thoughts on Machiavelli, Seattle 1969; R. Piekarski, Koncepcja cnót politycznych Machiavellego na tle elementów klasycznej etyki cnót, Gdańsk 2007.

${ }^{24}$ J. Ferrari, Histoire de la Raison d'État, Paris 1860, s. 235-265; F. Ercole, Guicciardini e la 'Ragion di Stato', „Rivista Internazionale di Filosofia del Diritto” 1942, nr 22, s. 359-420. 
katolicko-kontrreformacyjną odpowiedź na $K_{s i e ̨ c i a}{ }^{25}$. Definiował on rację stanu jako „wiedzę o środkach właściwych dla stworzenia, zachowania i powiększenia panowania" ${ }^{26}$. Jednak środków tych Botero nie widział w amoralnym makiawelizmie, lecz w przyroście liczby obywateli dzięki polityce pronatalistycznej, dbanie o zamożność, praworządność, państwową religię, naprawę obyczajów, wspieranie rodzimego rolnictwa, handlu i wytwórczości (protekcjonizm i szukanie rynków zbytu), walkę z korupcją urzędników, opiekę nad weteranami wojennymi i wdowami po poległych etc. Pisarz ten szczególnie akcentuje element demograficzny i majątkowy, stojąc na stanowisku, że państwo potrzebuje żołnierzy i podatków, a tych nie ma przy niskiej liczbie ludności i biedzie ${ }^{27}$. Władza polityczna winna służyć państwu przez swoją społeczną i ekonomiczną aktywność, skutkującą zwiększonymi możliwościami militarnymi. Aby tak działać, nie może jednak być ograniczona przez prawa fundamentalne, prawa tradycyjne stanowe i regionalne. Cała włoska renesansowa nauka o państwie, przyjmująca za naczelną kategorię rację stanu, na dalszy plan usuwa prawa tradycyjne i instytucje przedstawicielskie, stając po stronie rodzącego się absolutyzmu jako skutecznego narzędzia mobilizacji politycznej $^{28}$.

3. Reformacja i wojny religijne. W wyniku reformacji w 1517 r. wprowadzono do polityki europejskiej nowy podmiot lojalności politycznej-konfesję. Protestanccy książęta i poddani buntowali się przeciwko władcom zachowującym lojalność wobec Kościoła katolickiego i papieża, a katoliccy przeciwko tym zwierzchnikom, którzy przyjęli nową wiarę i usiłowali narzucić ją całemu państwu. W Europie doszło do serii wojen domowych na tle polityczno-konfesyjnym. Ireniczny pacyfizm głosiło tylko nieliczne grono filozofów i polityków. Większość elit i ludów, a nawet i władców, uznawała innowierców za bluźnierców, a istnienie wielości konfesji za wyraz moralnej i politycznej dezintegracji państwa. Rozmaite konfesje stanowiły zarazem regularne stronnictwa polityczne, a każde z nich chciało umocnić lub zdobyć władzę i siłą narzucić swoje wyznanie całemu państwu. Przedstawiciele religii panującej domagali się zniesienia reprezentacji stanowej i ograniczeń władzy suwerenów, aby ci mogli rozprawić się z innowiercami. Z kolei przedstawiciele konfesji opozycyjnych organizowali się w regularne stronnictwa

${ }^{25}$ R. Bireley, The Counter-Reformation Prince. Anti-Machiavellianism or Catholic Statecraft in Early Modern Europe, Chapel Hill 1990, s. 46-50; R. Descendre, L'état du monde. Giovanni Botero entre raison d'Etat et géopolitique, Genève 2009, s. 24-30.

${ }^{26}$ G. Botero, La ragion di stato, ks. I, Roma 2009 [1589], s. 7.

${ }^{27}$ Ibidem, ks. VIII, s. 123-138.

${ }^{28}$ R. Descendre, Sur l'effacement du modèle de la constitution mixte dans les discours italiens de la raison d'Etat: Botero, Boccalini et Zuccolo [w:] M. Gaille-Nikodimov (red.), Le gouvernement mixte. De l'idéal politique au monstre constitutionnel en Europe, XIIIe-XVII siècle, Saint-Étienne 2005, s. 71-94. 
i głosili prawo do oporu, by przeprowadzić rewolucję religijną, a zdobywszy władzę, osadzić sprzyjającą sobie dynastię lub władzę o innym ustroju, która siłą umocni nowe wyznanie i zlikwiduje fizycznie innowierców ${ }^{29}$.

\subsection{Dezintegracja praw fundamentalnych w XVI-XVII wieku}

\subsubsection{Ku absolutyzmowi: Francja}

Stan pełzającej lub rzeczywistej wojny domowej nie sprzyjał zachowaniu tradycyjnych konstytucji, które z reguły stały na przeszkodzie wzmocnieniu władzy bądź oddolnej rewolucji, głosząc ideał monarchii mieszanej i władzy ograniczonej. We Francji, gdzie monarchowie dość długo wahali się, czy stanąć po stronie katolików czy kalwinów, ostatecznie oba wyznania zaczęły głosić hasła demokratyczne i rewolucyjne, zaprzeczające monarchicznemu charakterowi praw fundamentalnych wiążących się z zasadami sukcesji ${ }^{30}$. W samym obozie monarchistycznym nad Sekwaną toczyła się dyskusja, jaki ustrój ma Francja w sytuacji, gdy doszło już do dezintegracji tradycyjnego porządku? Istotą dyskusji ustrojowych staje się pytanie: czy władca jest suwerenem absolutnym, mającym moc tworzenia, modyfikowania i uchylania zasad tradycyjnego ustroju, czy też musi rządzić w ich ramach? $\mathrm{Na}$ pytanie to udzielano wówczas trzech odpowiedzi ${ }^{31}$ :

A. Absolutyści-tradycjonaliści. Ten stosunkowo słabo dziś znany i raczej zapomniany kierunek wywodził suwerenność króla z zasad legizmu, prawa rzymskiego i kanonicznego, umieszczając go jednak w ramach średniowiecznych praw fundamentalnych i postrzegając jako osobę sakralną, z łaski Boga (Jean Feu, Jean Ferrault) ${ }^{32}$.

B. Le giści. Ich koncepcje są kontynuacją tradycji absolutyzmu późnomediewalnego, ale zrywają z nim pod względem argumentacji. Władza nie ma u nich sakralnego charakteru w rozumieniu średniowiecznym, gdyż odwołania do Boga mają charakter ogólnikowy, stanowią argument za wszechwładzą króla na wzór władzy boskiej. Stąd stawiane w starszej literaturze pytania o konfesję najbar-

${ }^{29}$ A. Wielomski, Myśl polityczna Reformacji i Kontrreformacji, t. I: Rewolucja protestancka, Warszawa 2013, s. 133-268.

30 J.J.R. Ibáñez, M. Penzi, 'Ius populi supra regem'. Concepciones y usos políticos del 'pueblo' en la liga radical católica francesa (1580-1610), „Historia Contemporánea” 2004, nr 28, s. 111145 (Liga Katolicka); V. De Caprariis, Propaganda e pensiero politico in Francia durante le guerre di religione, t. I: 1559-1572, Napoli 1959, s. 375-439 (stronnictwo hugenockie).

31 Por. A. Wielomski, Nacjonalizm wobec problemu Europy, Warszawa 2018, s. 114.

32 B. Paralisi, La Scuola di Orléans: un'epoca nuova del pensiero giuridico, „Studia et Documenta et Iuris" 1960, nr 26, s. 347-362; E. Sciacca, Le Radici teoriche dell'assolutismo nel pensiero politico francese de primo Cinquento (1498-1519), Milano 1975, s. 29-68. 
dziej znanego z legistów tej epoki, a mianowicie Jeana Bodina ${ }^{33}$. Rzeczywistym uzasadnieniem suwerenności monarszej jest skuteczność i wysoka racjonalność podejmowanych decyzji. Guillaume Budé w swojej słynnej rozprawie $O$ instytucji władcy (De l'institution du Prince, 1547) pisze:

Królowie [...] nie podlegają prawom i zarządzeniom swojego królestwa, jak inni ludzie, chyba że mają taką wolę. Zakładamy, że są tak doskonali w cnocie, tak wielce szlachetni, tak przesyceni sprawiedliwością, że nie trzeba im żadnej reguły, ani ustawy, ani groźby kary [...] ani konieczności posłuszeństwa, jak innym poddanym. Do rządzenia wystarczy im samo prawo boskie, mające autorytet BOGA suwerennego prawodawcy, a nie prawo ludzi, wedle których wszyscy ludzie są równi wobec prawa, bez względu na dystynkcje. [...] królowie wydają ordonanse, konstytucje, edykty chwilowe i stałe, ustanawiają dobre i godne pochwały reguły i zmiany, wszystko godne ich, reguły korzystne i zbawcze, dające dobry przykład, przynoszące im zaszczyt i dobre owoce. W ten sposób królowie nabywają nieśmiertelność imienia, wieczną chwałę i splendor w tym świecie oraz wieczne zbawienie na tamtym ${ }^{34}$.

Przypisywana władcom wyższa racjonalność powoduje, że legiści uznają ich niezdolność do czynienia źle (irracjonalnie). Budé dowodzi, że suwereni są „wyłączeni i immunizowani z chciwości, skąpstwa, ambicji, okrucieństwa, fałszywych podejrzeń, żądzy, niehonorowej rozkoszy i czczej małości”35. Stąd Bodinowska niechęć i pogarda dla króla-tyrana, bowiem zaprzeczałoby to jego wyższej racjonalności. Król-tyran to taki, który nastaje na religię, władzę ojcowską i własność poddanych. Dlatego (rzekomo) suwerenny Bodinowski król nie ma jeszcze mocy samodzielnego stanowienia podatków, bez zgody stanów ${ }^{36}$.

C. Konstytucjonaliści. Kierunek ten reprezentował przede wszystkim bp Claude de Seyssel, autor Wielkiej monarchii we Francji (La Grant Monarchie de France, 1520). Dowodzi on, że Francja jest monarchią opartą nie tylko na prawie salickim w kwestii dziedziczenia tronu. Do praw fundamentalnych zalicza także:

${ }_{33}$ Z. Izdebski, Poglady Jana Bodinusa na państwo i prawo [w:] J. Bodin, Sześć ksiag o Rzeczypospolitej, Warszawa 1958 [1576], s. XX, idem, Quelques observations sur les idées politiques de Jean Bodin, Łódź 1965, s. 8. Gwoli wyjaśnienia: politycznie rzecz biorąc J. Bodin jest zwolennikiem Ligi Katolickiej (S. Baldwin, Jean Bodin and the League, „Catholic Historical Review” 1937, nr 23, s. 160-184; P.L. Rose, The 'politique' and the prophet: Bodin and the Catholic League 1589-1594, „Historical Journal” 1978, nr 4, s. 783-808), ale prywatnie jest renesansowym synkretystą religijnym (E. Voegelin, Jean Bodin, München 2003, s. 68-88).

${ }^{34}$ G. Budé, De l'institution du Prince, Paris 1547, s. 20, 73.

${ }^{35}$ Ibidem, s. 104.

${ }^{36}$ P. King, The Ideology of Order. A Comparative Analysis of Jean Bodin and Thomas Hobbes, London 1974, s. 73-157; M. Isnardi-Parente, Jean Bodin su tirannide e signoria nella „, République”, „Il Pensiero Politico” 1981, nr 14, z. 1, s. 61-77. Jako egzemplifikację zob. J. Bodin, Sześć ksiąg..., ks. I, rozdz. 8, s. 111-147; ks. II, rozdz. 4, s. 276-280. 
(1) religię katolicką jako oficjalną konfesję państwa, wymaganą także od władcy; (2) pojęcie sprawiedliwości, które wyrażają francuskie parlamenty i izby obrachunkowe (w kwestiach podatkowych), mające moc vetowania lub korygowania ordonansów królewskich, gdyby te wymykały się tej cnocie; (3) ,politykę” (police), czyli prawo króla wydawania ordonansów będących ustawami powszechnymi; (4) zachowanie trójstanowej struktury społecznej (duchowieństwo, szlachta, lud) z możliwością awansu ze stanu niższego do wyższego ${ }^{37}$.

Zwraca w tej konstrukcji uwagę teoretyczna absolutna suwerenność króla, o ile jest katolikiem i rządzi sprawiedliwie, co w praktyce oznacza jego ograniczenie przez Kościół, parlamenty i izby obrachunkowe, mające moc kontroli sposobu wykonywania władzy. Seyssel uzasadnia to porównaniem do Boga, który jest wszechmocny, ale nie może czynić niesprawiedliwie. Króla dotyczy taka sama zasada, stąd instytucje kontrolne o charakterze konstytucyjnym ${ }^{38}$. Jak dodaje ten pisarz, suweren jest „wysłannikiem Opatrzności dla czynienia sprawiedliwości”, której norm sam nie tworzy, a jedynie nimi ,administruje" 39 .

Mimo wojen religijnych XVI w. we Francji utrzymuje się zatem przekonanie, że wszechwładzę króla ograniczają nie tylko prawa fundamentalne, lecz także tradycyjny ustrój państwa (konstytucjonaliści), a gdzie przynajmniej szanowana jest religia, prawo ojcowskie, własność prywatna (legiści). Monarsze samodzierżawie hamowane jest przekonaniem, że król wprawdzie jest suwerenem, ale nie może czynić źle, co powoduje, iż jego władza podlega racjonalizującej jego prawa i rozkazy kontroli przez tradycyjne ciała korporacyjne, co wyraża formuła rządów „króla w radzie" (Roi en son Conseil) ${ }^{40}$. Oto konstytucja wczesnonowożytnej Francji.

Niestety, model konstytucyjny nie przetrwał chaosu wojen religijnych wewnętrznych i zewnętrznych, szczególnie wojny trzydziestoletniej (1618-1648). Wojny te wymagały centralizacji państwa, zwiększenia fiskalizmu i skokowego wzrostu liczby żołnierzy. Cicha rewolucja polityczna ciągnęła się przez prawie sto lat (1624-1715), wiążąc się z nazwiskami kard. Armanda de Richelieu, Jeana-Baptiste'a Colberta i Ludwika XIV. Gdy Richelieu w 1624 r. obejmował faktyczną władzę nad Francją, państwo to posiadało 30 tys. stałych najemnych żołnierzy. Gdy umierał po osiemnastu latach rządów, Francja miała już 250 tys. żołnierzy ${ }^{41}$. Liczba ta prawie podwoiła się za panowania Ludwika XIV.

Jeśli w ciągu niecałych stu lat armia państwa zwiększa swoją liczbę piętnastokrotnie, to musi się to odbyć kosztem przeprowadzenia w kraju znaczącej mobili-

${ }^{37}$ C. de Seyssel, La Monarchie de France, Paris 2012 [1520], s. 37-70.

38 Ibidem, s. 60.

${ }^{39}$ Ibidem, s. 96, 98.

${ }^{40}$ A. Jouanna, Le Pouvoir absolu. Naissance de l'imaginaire politique de la royauté, Paris 2013, s. 72-74.

${ }^{41}$ Y.-M. Bercé, La naissance dramatique de l'absoloutisme, 1598-1661, Paris 1992, s. 148. 
zacji politycznej, za pomocą centralizacji, fiskalizmu i wzrostu regulacyjnej funkcji państwa. Tak też było w przypadku Francji, która wplątała się w szereg wojen z Habsburgami, których posiadłości otaczały ją ze wszystkich stron. Spowodowało to stopniową marginalizację tez konstytucjonalistów. Teoretycy monarchistyczni szybko zaczynają utożsamiać państwo i suwerenność z królem, zaprzeczając korporacyjnym podstawom monarchii stanowej. Charles Loyseau pisze już w 1608 r., że „suweren nadaje formę państwu, a samego pojęcia państwa używamy wtedy, gdy posiada suwerena dającego mu moc, dzięki czemu państwo wrasta i samo siebie ustanawia" ${ }^{2}$. W 1632 r. Cardin Le Bret rzuca słynną maksymę, że „suwerenność jest równie niepodzielna jak punkt $w$ geometrii" ${ }^{\prime 3}$. Z kolei Jean-Louis Guez de Balzac pisze:

Król [...] jest kierowany przez najczystsze światło rozumu powszechnego. Jego najważniejsze decyzje rodzą się z asystencją Niebios. Większość rad, które dostaje, ma źródło w nadnaturalnej mądrości, ponieważ zwykle pochodzą bezpośrednio od Boga, a nie od ludzi. Znajduje on prawdę zwykle już w chwilę po rozpoczęciu rozważań, a są one tak racjonalne i trafne, że ci, którzy doradzają mu, zwykle przytakują jego pierwszemu impulsowi, nie wnosząc już niczego nowego. [...]. Dlatego jego osąd jest spokojny i beznamiętny, widzi rzeczy w czystości ich bytu, gdy my je postrzegamy poprzez nasze namiętności ${ }^{44}$.

W piśmiennictwie tej epoki we Francji często spotykamy motyw, że królowie odpowiadają po śmierci przed Bogiem nie za zwykłe grzechy, jak wszyscy ludzie, lecz zdają rachunek ze swojej pracy dla państwa i realizacji racji stanu, pojętej dość makiawelicznie, gdyż oznaczającej rozejście się w polityce racji politycznej i racji moralnej. Dla przykładu: król katolicki winien w kraju tępić protestantyzm, ale wolno mu popierać partię protestancką przeciwko katolickiemu cesarzowi w Rzeszy, gdyż taka jest racja stanu państwa ${ }^{45}$. Nadworny kapelan Ludwika XIV bp Jacques Bossuet nie zawahał się nawet wygłosić publicznie kazania na dworze, w którym stwierdził, że jako przewodnik duchowy wielkiego polityka w pełni rozumie zachowanie Poncjusza Piłata, który - nie wiedząc, że to Syn Boży - wydał Jezusa na śmierć, mimo że nie widział jego winy. W danych okolicznościach posłanie na męczeńską śmierć niewinnego stanowiło cenę za zachowanie spokoju publicznego, czyli było zgodne z racją stanu starożytnego Rzymu ${ }^{46}$.

${ }^{42}$ Ch. Loyseau, Traité des seigneuries [1608] [w:] idem, Cinq livres du droict des offices, avec la livre des seigneuries et celui des ordres, ks. III, Paris 1613, s. 31.

${ }^{43}$ C. Le Bret, De la souveraineté de Roy, Paris 1689 [1632], s. 19.

44 J.-L. Guez de Balzac, Le Prince, Paris 1631, s. 274-275, 314.

${ }^{45}$ A. de Richelieu, Oeuvres, Paris 1933, s. 54-56. Szerzej: E. Thuau, Raison d'Etat et pensée politique à l'époque de Richelieu, Paris 2000, s. 307-318.

46 J. Bossuet, Politique de Bossuet (red. J. Truchet), Paris 1966, s. 240-241. 
Słowem, w osobie króla francuskiego łączą się suwerenność, wyższa racjonalność i oddzielna dla władców moralność. Czy dla istoty tak szlachetnej i wzniosłej tradycyjna konstytucja królestwa i jego prawa fundamentalne mogą być przeszkodą? W literaturze francuskiej XVII w. na złamanie tradycyjnej konstytucji przez suwerena ukuto nawet specjalne pojęcie: coup d'État ${ }^{47}$. Co ciekawe, dziś ten termin oznacza zamach stanu.

Ludwik XIV dwukrotnie podeptał prawa fundamentalne królestwa w latach 1713 i 1714 w kwestii dziedziczenia praw do tronu:

A. Pokój w Utrechcie. W 1713 r. na mocy tego pokoju zakończyła się wieloletnia wojna o sukcesję hiszpańską, a wnuk Ludwika XIV, Filip Andegaweński, wstąpił na tron Hiszpanii jako Filip V. Ponieważ jednak połączenie przez Burbona tronów Francji i Hiszpanii uważano za groźne dla równowagi europejskiej, koalicja antyfrancuska wymusiła na Ludwiku XIV rezygnację jego wnuka z prawa do tronu Francji. Akt takiej rezygnacji był explicite niezgodny z prawami fundamentalnymi Francji, gdyż na mocy prawa salickiego żaden władca ani spadkobierca nie mógł zrzec się prawa do tronu, gdyż to Bóg jest dysponentem prawa do panowania i realizuje je poprzez porządek dziedziczenia. Dlatego współcześni francuscy legitymiści dowodzą, że jego zrzeczenie się było nieważne, ponieważ „Ludwik XIV nie miał mocy modyfikowania praw fundamentalnych królestwa", które są „prawem stałym, niezmiennym, niedotykalnym co do zasady dziedziczenia przez primogeniturę męską z prawego łoża”, co nakazuje uznać je za „nieważne”48.

B. Edykt o sukcesji. Gdy w 1713 r. Filip Andegaweński utracił prawa do sukcesji, a w tym samym czasie zmarł drugi syn Ludwika XIV, jego dwóch wnuków i jeden prawnuk, Francji zaczęło grozić wygaśnięcie dynastii. Jedyny dziedzic legalny do tronu był kilkuletnim dzieckiem. W tej sytuacji, na wszelki wypadek, król wydał w 1714 r. edykt, w którym uznał, że w razie śmierci ostatniego legalnego następcy prawa do tronu odziedziczą jego dwaj nieślubni synowie z nieformalnego związku z Mme de Montespan: diuk Maine i hrabia Tuluzy. Edykt uznający prawa do tronu synów z nieprawego łoża stanowił zaprzeczenie prawa salickiego. W języku francuskim przymiotnik légitime oznacza zarówno prawowity (legitymistyczny), jak i z prawego łoża ${ }^{49}$.

Mimo dotychczasowych badań francuskiej myśli politycznej XVII w. nieznany jest mi żaden głos z epoki w obronie podeptanych praw fundamentalnych. Świadczy to prawdopodobnie o samoistnym zaniku tej idei we francuskim społeczeństwie.

Podobnie było z postulatami konstytucjonalistów w rodzaju Seyssela. Badacze uważają, że po wojnach religijnych z drugiej połowy XVI w. we Francji nie

${ }^{47}$ E. Thuau, Raison d'Etat..., s. 395.

48 [Anonim], Manifeste Légitimiste, Fontenay-le-Comte 2008, s. 82.

49 A. Jouanna, Le Prince absolu. Apogée et déclin de l'imaginaire monarchique, Paris 2014, s. $199-200$. 
było klimatu społecznego dla obrony konstytucjonalizmu. W XVII w. Francuzi gremialnie popierali katolicką monarchię absolutną, widząc w niej gwarancję pokoju publicznego ${ }^{50}$. Gwałtowna zwyżka podatków nie była jednak popularna. Rosnący fiskalizm stał w sprzeczności z zasadami monarchii stanowej i konstytucyjnej. Dlatego od 1614 r. stany generalne nie są zwoływane. Zanika też zwyczaj gromadzenia stanów regionalnych, utrzymując się tylko w kilku prowincjach (Bretania, Burgundia, Delfinat, Prowansja, Langwedocja, Gujenna, Béarne), ale i one w XVII w. coraz bardziej ulegają presji centralistycznej, stając się maszynką do uchwalania żądanych danin ${ }^{51}$. Ostatnim bastionem oporu konstytucjonalistów - aż po 1789 rok i wybuch rewolucji - pozostają parlamenty, szczególnie zaś wiecznie nieposłuszny władzy parlament paryski ${ }^{52}$.

Armand de Richelieu i Ludwik XVI krok po kroku rozebrali nowożytną konstytucję Francji. Dlatego ich sympatyk Jacques Bainville, uważając, że zaczęli sprawować nieograniczoną władzę, uznał ich za pierwszych francuskich dyktatorów w dziejach, a ich krytyk Feliks Koneczny - za twórców bizantynizmu nad Sekwaną ${ }^{53}$.

\subsubsection{Ku parlamentaryzmowi: Anglia}

W Anglii także doszło do dezintegracji praw fundamentalnych i stało się to $\mathrm{z}$ inicjatywy królów. Ze średniowiecza zachował się w tym kraju pogląd, że istotą konstytucji są współrządy króla z parlamentem reprezentującym stany („,król w parlamencie"), przy czym wzajemne kompetencje obydwu organów nie były jasno rozdzielone. Na początku XVI w. równowaga ta została zaburzona za rządów Tudorów na korzyść monarchy. Efektem tej przewagi była arbitralna decyzja Henryka VIII o ogłoszeniu aktu supremacji i zerwaniu z Rzymem (1534). Uległy parlament - na swoją zgubę - poparł monarchę, ponieważ w schizmie widziano akt patriotyczny - deklarację suwerenności Anglii wobec katolickich ośrodków uniwersalistycznych: papieża i cesarza ${ }^{54}$.

${ }^{50}$ Ibidem, s. 3-15.

${ }^{51}$ Ibidem, s. 131-139.

${ }^{52}$ W. Doyle, The parliaments [w:] K.M. Baker (red.), The French Revolution and the Creation of Modern Political Culture, t. III: The political Culture of the Old Regime, Oxford 1987, s. 157-168; F. di Donato, Constitutionalisme et idéologie de robe. L'évolution de la théorie juridico-politique de Murard et Le Paige à Chanlaire et Mably, „Annales. Histoire, Sciences Sociales” 1997, t. LII, nr 4, s. 821-852.

53 J. Bainville, Les dictateurs, Paris 1996, s. 53-64; F. Koneczny, Cywilizacja bizantyjska, Komorów 2006, s. 326-327, 336-337.

${ }^{54}$ J.L. Aranguren, Religión y Politica: el Anglicanismo, „Revista de Estudios Politicos” 1948, nr 37-38, s. 130-131; J. Fueyo Alvarez, La teologia politica del Estado-nación y el anglicanismo politico, „Revista de Estudios Politicos” 1968, nr 157, s. 1-13; R. Ottow, Die Debatte über Kirche, 
Schizma miała jednak poważne konsekwencje dla wyspiarskiego systemu konstytucyjnego. Za jej pomocą król został bardzo wzmocniony. Po pierwsze, nacjonalizując, a następnie wyprzedając ziemię kościelną ( $40 \%$ areału w kraju), stworzył potężne stronnictwo rojalistyczne, zainteresowane utrzymaniem władzy przez Henryka VIII i obawiające się ewentualnego zwycięstwa kontrreformacji ${ }^{55}$. Po drugie, w wyniku schizmy władca stał się głową lokalnego Kościoła, konstytuując jego prawdy wiary i czyniąc z duchownych część aparatu urzędniczego podległego dworowi. Lojaliści chętnie przywoływali tu model cezaropapizmu sprzed reformy gregoriańskiej, gdzie król angielski (przez zasiedzenie) przejął uprawnienia imperialne względem wspólnoty eklezjalnej ${ }^{56}$.

Fakt, że Henryk VIII i jego następcy stali się naczelnikami religijnymi w warstwie idei, miał kluczowe znaczenie, gdyż przyczyniał się do sakralizacji osoby monarchy. Czy bowiem król będący głową Kościoła może współdzielić władzę z parlamentem wybieranym przez laikat? W krytycznych dla Anglii latach 30 . XVI w., gdy ważyła się sprawa schizmy, lojaliści nauczali, że poddani winni są królowi - pochodzącemu z Bożej łaski - posłuszeństwo w każdej sytuacji, nawet gdy zrywa z Kościołem i pociąga za sobą poddanych, o ile tylko nie wyrzeka się Boga ${ }^{57}$. Stąd zjawisko zwane erastianizmem, czyli prawo każdego władcy do zmiany konfesji państwowej wedle własnego uznania ${ }^{58}$, praktykowane przez kolejnych monarchów: anglikanizm został ustanowiony przez Henryka VIII (1534), powrót do katolicyzmu - przez Marię I Tudor (1555), a odbudowa anglikanizmu z naleciałościami kalwińskimi - przez Elżbietę I (1559).

W narracji partii dworskiej parlament był coraz bardziej redukowany w swoich kompetencjach, choćby dlatego, że jego członkowie podlegali królowi w sprawach konfesyjnych. Coraz rzadziej mówiono o tradycyjnych współrządach króla z parlamentem, a coraz częściej o całkowitej suwerenności władcy, który łaskawie pozwala ludowi wyrazić swoje opinie za pomocą instytucji parlamentarnych, stanowiących tylko moc opiniodawczą, w dodatku tylko czasowo delegowaną przez suwerena. Pisano o „nowej monarchii” i o absolutyzmie „króla w parlamencie”,

Recht und Souveränität zu Beginn der englischen Reformation, „Archiv für Rechts- und Sozialphilosophie" 2006, nr 4, s. 478-504.

${ }_{55}$ G.M. Travelyan, Historia społeczna Anglii, Warszawa 1961, s. 117.

${ }^{56}$ E. Fox, Opus eximium de vera diferentia regiae potestatis et ecclesiasticae, et quae sit ipsa veritas ac virtus utriusque, London 1534, s. 29-31; S. Gardiner, De vera obedientia, London 1535, s. $80-81$.

57 R.L. Greaves, Concepts of Political Obedience in Late Tudor England: Conflicting Perspectives, „Journal of British Studies” 1982, t. XXII, nr 1, s. 27.

58 J.N. Figgis, The Divine Right of Kinges, New York 1965, s. 5-8; J.P. Sommerville, Hobbes, Selden, Erastianism, and the history of the Jews [w:] G.A.J. Rogers, T. Sorell (red.), Hobbes and History, London 2000, s. 168-174. 
nie widząc $\mathrm{w}$ tym haśle wewnętrznej sprzeczności ${ }^{59}$. Równocześnie podkreślano, że władca - jako pochodzący od Boga i któremu należne jest absolutne posłuszeństwo - może rządzić także bez konsultacji z izbami. Parlament wprawdzie istniał, ale w oficjalnej doktrynie głoszono, że w sumie nie jest konieczny i pełni tylko funkcję doradczą, w pokorze wyrażając potrzeby i skargi poddanych przed monarszym majestatem. Dowodzono, że król wprawdzie sprawuje władzę wespół z nim, ale nie istnieje legalny sposób na powstrzymanie jego suwerennej woli. Gdyby suweren nie konsultował swoich decyzji z parlamentem, to i tak nie może rządzić źle (king can do not wrong), a prawo do jego oceny posiada wyłącznie Bóg, ale nie jego poddani. W miejsce tradycyjnego konstytucjonalizmu pojawia się teoria „boskiego prawa królów” (Divine Right of Kinges), czyli idea, że osoba monarchy pochodzi bezpośrednio z Bożej łaski i tylko Bóg ma prawo go osądzać, a nie ludzie lub poszczególne kościoły ${ }^{60}$.

Sakralizacja władzy królewskiej stała się szczególnie widoczna za panowania Jakuba VI/I Stuarta, który przy okazji był najwybitniejszym myślicielem partii królewskiej tego okresu. Już w 1599 r., czyli jeszcze przed wstąpieniem na tron angielski, jego traktat pedagogiczny o wychowaniu króla Szkocji, zatytułowany

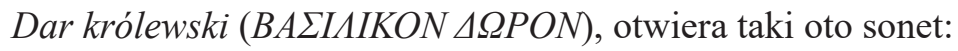

Bóg nie nazywa daremnie królów mianem bogów,

Gdyż na swoich tronach dzierżą berło i moc:

I gdy ich poddani są im posłuszni,

To klękają przed nimi ${ }^{61}$.

W słynnej mowie w parlamencie w 1610 r., już jako władca angielsko-szkocki, Jakub VI/I ogłosił:

[...] królowie są nie tylko pomazańcami BOGA na ziemi i zasiadają na tronie BOGA, ale nawet przez samego BOGA nazywani są Bogami. [...] Królowie słusznie nazywani są bogami, gdyż na wzór Boga sprawują władzę na ziemi. Jeśli rozważalibyśmy atrybuty Boga, to odnajdziemy je także w osobie króla. Bóg posiada moc tworzenia, niszczenia, czynienia lub zaniechania czynienia wedle swojego kaprysu, dawania życia, karania śmiercią, sądzenia wszystkich, samemu nie będąc sądzonym przez nikogo; obniżania i podwyższania rzeczy wedle swojego kaprysu. Także do Boga należy ciało i dusza. Król ma podobną władzę: tworzy lub niszczy swoich poddanych; ma moc podnoszenia i obniżania ich w hierarchii; prawo życia i śmierci; sądzenia wszystkich swoich poddanych we wszelkich sprawach, a samemu odpowiadając tylko przed Bogiem. Może obniżać i podwyższać

${ }^{59}$ L. D'Avack, Costituzione e Rivoluzione. La controversia sulla sovranità legale nell'Inghilterra del'600, Milano 2000, s. 20-21.

${ }^{60}$ J.N. Figgis, The Divine Right...

${ }^{61} \mathrm{Jakub} \mathrm{VI} / \mathrm{I}, B A \Sigma I \Lambda I K O N \triangle \Omega P O N$ ou present roial, Lyon 1605 [1599], s. 11. 
rzeczy i traktować ludzi jak zwierzęta na polowaniu. Może strącić tak biskupa, jak rycerza, może ich wywyższyć lub poniżyć, zrobić, co chce, z ich pieniędzmi. A i tak królowi przynależy miłość ich duszy i służba ich ciał ${ }^{62}$.

Czy monarcha, który sam postrzega się w ten sposób, może rządzić w ramach tradycyjnej konstytucji, szanując stare prawa i uprawnienia stanów? Oczywiście nie, ponieważ Jakub VI/I, na wzór patrymonialny, uważa się za właściciela swoich poddanych i wszystkich ich rzeczy, kumulując (przynajmniej w teorii) całą własność w swoich rękach. Odrzuca współrządy z parlamentem, gdyż znaczyłoby to, że sam nie jest dysponentem całej suwerenności; uważa, iż ma prawo stanowienia ustaw w postaci swoich ordonansów (legibus solutus); posiada też moc rewidowania wyroków sądowych ${ }^{63}$. Dlatego badacze określają go mianem „rewolucjonisty” i burzyciela tradycyjnej konstytucji ${ }^{64}$.

Podobne poglądy polityczne miał następny ze Stuartów, a mianowicie Karol I, które wyraził w Odpowiedzi na dziewiętnaście propozycji (Answer to the Ninteen Propositions, 1642). W odpowiedzi na żądania zbuntowanego już wówczas parlamentu władca głosi, że jako monarcha: (1) posiada prawo stanowienia praw i nakładania podatków bez zgody parlamentu; (2) nie podlega jurysdykcji i kontroli parlamentu; (3) ma monopol na rekrutację wojska i dowodzenie nim; (4) ma monopol na prowadzenie polityki zagranicznej. Uznaje wprawdzie izby za część angielskiej konstytucji, ale o kompetencjach doradczych, negując tradycyjny pogląd o suwerenności króla w parlamencie. Monarcha przedstawił tutaj ideę suwerenności skupionej niepodzielnie we własnych rękach ${ }^{65}$.

Praktyczne przesunięcie centralnego ośrodka ze współrządów króla z parlamentem ku monarsze wywołało znaczne niezadowolenie społeczne, które pokrywało się z podziałami konfesyjnymi. Partię dworską stanowili anglikanie i (półoficjalnie) katolicy, gdy obrońcy tradycyjnej konstytucji rekrutowali się spośród purytanów. Doprowadziło to w połowie XVII w. do rewolucji angielskiej i wojny domowej, na poły religijnej, na poły konstytucyjnej ${ }^{66}$. Skupię się tu jedynie na problemie ustrojowym.

Pierwotną opozycję stanowili antykwaryści, czyli prawnicy ze szkoły Edwarda Cooke'a, który jeszcze za panowania Jakuba VI/I napisał kilkanaście traktatów na temat istoty i obowiązywalności starych angielskich praw, cofając się w swoich poszukiwaniach do epoki sprzed normańskiego najazdu. George Gooch charakte-

62 Jakub VI/I, Political Writings, Cambridge 2006, s. 181.

${ }^{63}$ L. D'Avack, La ragione dei Re. Il pensiero politico di Giacomo I, Milano 1974, s. 47-55.

${ }^{64}$ Ibidem, s. 250; B. Szlachta, Monarchia prawa..., s. 13.

${ }^{65}$ Karol I Stuart, The King's Answer to the Nineteen Propositions [1642], droitpolitique.com [dostęp: 22.02.2019].

66 J. Morill, The Nature of the English Revolution, London 1993, s. 33-44; N. Carlin, The causes of the English Civil War, Oxford 1999, passim, zwłaszcza s. 37-38. 
ryzuje Cooke'a jako ,jednego z najbardziej konserwatywnych ludzi, którzy kiedykolwiek żyli”, którego interesowała wyłącznie „mądrość przodków” i dla którego „prawo Anglii było religią, której był arcykapłanem, interpretatorem jej tajemnic i obrońcą jej świętości”"67. Jednak konserwatyzm ten ma charakter pozorny, gdyż celem antykwarystów była rewolucja ubrana w szaty konserwatywne. Chodziło o kontestację władzy Stuartów za pomocą aktów prawnych z wczesnego średniowiecza, sprzed ponad 600 lat, gdy nie istniało jeszcze państwo suwerenne oparte na prawie publicznym. W tej pseudotradycjonalistycznej koncepcji w ogóle nie było prawa publicznego. Władza monarsza miała wynikać z kontraktu prywatnego między władcą a poddanymi. Dlatego John Selden wywodził ją z mediewalnego prawa prywatnego, widząc $\mathrm{w}$ niej kontrakt, $\mathrm{z}$ którego wynika prawo do oporu wobec tyranii:

Aby wiedzieć jaki rodzaj posłuszeństwa jesteśmy zobowiązani wobec władcy, musimy zajrzeć do kontraktu między nim a poddanymi, tak jak trzeba zobaczyć umowę dzierżawną, aby dowiedzieć się, ile ma płacić panu ziemskiemu dzierżawca. Gdy umowa zostaje złamana, nie ma osoby trzeciej, która mogłaby sprawę osądzić. Wtedy należy chwycić za broń ${ }^{68}$.

Teorię przewagi parlamentu nad władcą przejęli od antykwarystów prezbiterianie. William Prynne w rozprawie Suwerenna wtadza parlamentów i królestw (The Sovereign Power of Parliaments and Kingdoms, 1643) domaga się radykalnego ograniczenia władzy króla na korzyść Izby Gmin. Głosi następujący program: (1) odebranie władcy prawa stanowienia podatków i nowych praw ${ }^{69}$; (2) przejęcie z jego rąk prawa powoływania i odwoływania ministrów; (3) przejęcie kontroli nad wojskiem i flotą; (4) zmuszenie króla do zgody na kalwinizację Kościoła anglikańskiego; (5) marginalizacja Izby Lordów; (6) likwidacja panowania arystokracji, m.in. poprzez eliminację języka francuskiego, którym nie posługuje się gmin. Słowem, purytanie dążyli do przekształcenia monarchii zmierzającej ku absolutyzmowi w monarchię parlamentarną, gdzie roi regne, mais ne gouverne $\operatorname{pas}^{70}$. Prynne zdaje się dopuszczać prawo do oporu wobec króla, ale nie chce tej idei wyrazić expressis verbis.

Punkt zwrotny w prezbiteriańskim postrzeganiu świata to 1645 rok, gdy stronnictwo ostatecznie rezygnuje z porozumienia z królem i ogłasza konieczność ustanowienia republiki ${ }^{71}$. Mimo że postulatów republikańskich nie da się uzasad-

${ }^{67}$ G.P. Gooch, Political Thought in England, London 1914, s. 62-63.

${ }^{68}$ Ibidem, s. 74.

69 W. Prynne, The Sovereign Power of Parliaments and Kingdoms, ks. II, London 1643, s. 65-79.

${ }^{70}$ Ibidem, ks. IV, s. 14-36.

${ }^{71}$ C.P. Gooch, The History of English democratic Ideas in the Seventeenth Century, Cambridge 1898, s. 126. 
nić za pomocą argumentów antykwarycznych, to purytanie nadal działają pod pretekstem obrony starych praw. Proces wytoczony pochwyconemu Karolowi I został przedstawiony jako sąd nad tyranem w imię obrony praw króla-instytucji przeciwko królowi-osobie, który miał przeistoczyć się w tyrana ${ }^{72}$. Równocześnie, także w niezgodzie z dawnymi prawami, zniesiono Izbę Lordów i episkopalizm w Kościele. Jednoizbowy parlament uzurpował sobie sprawowanie pełnej suwerenności. Konstytucyjny system rządów króla z parlamentem przekształcił się w model konserwatywnej społecznie republiki, gdzie prawa polityczne posiadało ok. $10 \%$ dorosłych mężczyzn ${ }^{73}$.

Wraz z męczeńską śmiercią Karola I (1649) nastąpiła ostateczna dezintegracja konstytucji Anglii, a wyłaniające się z obozu rewolucyjnego coraz bardziej radykalne stronnictwa (independenci, lewellerzy, diggerzy, baptyści, kwakrzy, Piąta Monarchia etc.) głosiły coraz bardziej ekstremistyczne postulaty. Spośród radykałów na szczególną uwagę zasługują lewellerzy, gdyż wystąpili z nowatorską wówczas propozycją nadania Anglii, rewolucyjnej w treści, demokratycznej konstytucji pisanej (paramount law), gdzie zostałyby szczegółowo ujęte nie tylko zasady nowego ustroju, ale także przyrodzone prawa ludu jako całości oraz uprawnienia jednostek ${ }^{74}$.

Anglicy wiele zrobili w następnym stuleciu, aby zatrzeć w pamięci wydarzenia rewolucji angielskiej, do tego stopnia, że chwalił ją nawet Edmund Burke i przeciwstawiał jej radykalizm rewolucji francuskiej ${ }^{75}$. Działo się tak dlatego, że w monarchicznej formie państwa nie pozostawiła widocznych śladów, skoro ostatecznie restaurowano monarchię i Izbę Lordów w państwie, a anglikanizm i episkopalizm w Kościele. W rzeczywistości całkowicie zachwiała dotychczasową konstytucją, prowadząc do formuły postulowanej przez prezbiterian: król panuje, ale nie rządzi. O ile w XVII w. we Francji konstytucyjna równowaga polityczna zachwiała się na rzecz wszechwładzy króla, o tyle w Anglii - na rzecz parlamentu.

\subsubsection{Ku dezintegracji: Sacrum Imperium}

Sytuacja prawno-polityczna w Cesarstwie była bardziej skomplikowana niż we Francji i w Anglii, które już w średniowieczu ukształtowały się jako państwa

${ }^{72}$ E. Kantorowicz, Dwa ciała króla..., s. 15-17.

${ }^{73}$ T. Tulejski, Od Hookera do Benthama. Eseje z angielskiej myśli ustrojowej, Łódź 2018, s. 141 .

${ }^{74}$ H.N. Brailsford, Levellers and the English Revolution, Stanford 1993, s. 96-143; R. Cueva Fernández, Los Levellers y el Agreement: nacia la teoria constitucional moderna, „Universitas” 2006, nr 4, s. 83-96; idem, Los 'Agreements of the people'y los Levellers. La lucha por un nuevo modelo politico en la Inglaterra de mediados del siglo XVII, „Revista Electronica de Historia Constitucional" 2008, nr 9, dialnet.unirioja.es [dostęp: 20.11.2011].

${ }^{75}$ E. Burke, Refleksje o rewolucji we Francji, Warszawa 1994 [1790], s. 36-50. 
narodowe. Badacze dziejów narodów i nacjonalizmów nie mają wątpliwości, że w czasie wojny stuletniej (1337-1453) ukształtowały się te dwa narody, ponieważ lojalność wobec własnego narodu i jego państwa stała się w świadomości powszechnej obu społeczeństw prymarna w stosunku do dynastycznej (legitymizm), stanowej i regionalnej ${ }^{76}$. Dlatego tamtejsze spory konstytucyjne nie dotyczą istnienia samego państwa i jego granic. W tym czasie Sacrum Imperium nie ma zdelimitowanych granic: (1) z punktu widzenia doktrynalnego wchodzi w jego skład cały świat chrześcijański (a może nawet i cały świat); (2) z punktu widzenia prawnego są to tylko tereny mniej więcej odpowiadające krajom niemieckojęzycznym; (3) w praktyce mamy coś w rodzaju państwa - federalnego lub konfederacji - złożonego z ponad 1,5 tys. królestw, księstw, posiadłości wolnych rycerzy i wolnych miast ${ }^{77}$. Nie ma także świadomego swojego jestestwa narodu niemieckiego, a jedynie liczne regionalne etnie, zamieszkujące rozliczne Heimaty.

Ta specyfika świata niemieckojęzycznego wytwarza odmienny problem konstytucyjny. Wszystkie spory ustrojowe we Francji i w Anglii można rozumieć jako Bodinowski spór o oznaczenie suwerena, czyli tego, kto posiada pełnię władzy. Obydwa kraje wychodzą od postśredniowiecznej formuły monarchii stanowej i podziału władzy między króla i parlament (Anglia) lub króla i stany generalne (Francja), aby ostatecznie przyznać pełnię suwerenności jednej z tych instytucji. W Sacrum Imperium problem konstytucyjny ma zupełnie inny charakter i nie dotyczy relacji między Sejmem Rzeszy a cesarzem, lecz integralności imperium. $\mathrm{Z}$ powodu braku państwa narodowego pojawił się następujący dylemat: czy Cesarstwo jest jednym państwem federalnym, opartym na feudalnej zasadzie suzeren-lennik, gdzie poszczególni królowie, książęta i wolne miasta są zobowiązani wykonywać rozkazy imperatora i ustawy Sejmu Rzeszy, czy też jest luźną konfederacją suwerennych państewek terytorialnych, które tradycyjnie współpracują ze sobą na mocy decyzji wypracowywanych przez Sejm Rzeszy, ale bez prawnego przymusu kooperacji ${ }^{78}$ Federacja lub konfederacja - oto pytanie fundamentalne.

Miarą panującego chaosu było to, że Cesarstwo nie posiadało formalnie ustalonej jednej nazwy. Nazwa Heiliges Römisches Reich Deutscher Nation upowszechniła się dopiero w XIX w., podczas gdy w XVI w. posługiwano się kilkunastoma

${ }^{76}$ Zob. klasyczne prace: A. Hastings, The Construction of Nationhood: Ethnicity, Religion and Nationalism, Cambridge 1997, s. 33-66 (Anglia); C. Beaune, Naissance de la nation France, Paris 1985 (Francja).

77 A. Wielomski, Uwagi dotyczace „,niemieckości” cesarstwa w średniowieczu, „Polski Przegląd Stosunków Międzynarodowych" 2018, nr 8, s. 9-48.

${ }^{78}$ Ustrój Cesarstwa w XVI w. przedstawia np. K. Koranyi, Powszechna historia państwa i prawa $w$ zarysie, t. II, Warszawa 1955, s. 409-414. 
podobnymi, zawierającymi słowo „cesarstwo" 79 . Nie miało ani stolicy, ani wspólnej armii. Problem ten trafnie ujmuje historyk państwa i prawa Michael Stolleis:

To gmach scementowany przy użyciu podobnych języków, historii, związków feudalnych i umów, jak i przez symbole i wspólne rytuały, ale w sumie gmach niezbyt zdolny do wspólnego działania, skąpo wyposażony w realnie funkcjonujące instytucje, bez własnej armii, własnych finansów, własnych obywateli, bez ustalonych granic. Słowem, nie jest to „państwo” w nowoczesnym rozumieniu tego terminu ${ }^{80}$.

Cesarstwo to zlepek większych i mniejszych podmiotów politycznych, z których jedne podlegają bezpośrednio cesarzowi (posiadłości Habsburgów), inne są w nim w sojuszu (południowa Rzesza), a jeszcze inne dążą do emancypacji politycznej i osiągnięcia suwerennej państwowości (środkowe i północne Niemcy). Trudno tu mówić o suwerenności i suwerenie, raczej o zlepku terytoriów na różnym poziomie integracji wobec konstytucyjnego centrum. Stąd o modelu imperialnym tak chętnie mówią dzisiejsi entuzjaści Unii Europejskiej, którzy chcą usunąć ze słownika politycznego pojęcie suwerenności ${ }^{81}$.

Trudno orzec, jak zakończyłby się ten spór prawny o federację lub konfederację, gdyby nie pojawienie się w 1517 r. Marcina Lutra i nastanie reformacji. Zwolennicy rozwiązania konfederacyjnego dostali w tym momencie do ręki dobrą broń, mającą poparcie niemieckich etni: luteranizm. Gdy po stronie Lutra opowiedzieli się książęta z północnych Niemiec, którzy dali mu schronienie, cesarz zażądał jego wydania z wyraźną intencją osądzenia go za herezję i spalenia na stosie. Rozpoczął się wówczas spór kompetencyjny pomiędzy władzą centralną a książętami, czy cesarz może zmusić książęta do wydania mu poszukiwanego heretyka ${ }^{82}$. Spór z czysto konstytucyjnego szybko przekształcił się w doktrynalny, gdy Luter uznał, że biskup Rzymu jest Antychrystem, a popierający go cesarz jest jego pomocnikiem. W efekcie reformator ogłosił, że władcy przyjmujący właściwą (luterańską) interpretację litery biblijnej nie są zobowiązani do posłuszeństwa imperatorowi. Wtedy doszło do sojuszu nowej konfesji ze starymi roszczeniami prawnymi książąt do emancypacji spod władzy cesarskiej i wybicia się na suwerenność ${ }^{83}$.

Gdy w literaturze przedmiotu napisano wiele tomów i artykułów na temat Luterskiej teorii absolutnego posłuszeństwa wobec władzy, prawie całkowicie

79 V.R. Castro Gómez, Pensado la nación. Sacrum Imperium - teütsche landern-Deutschland, Frankfurt am Main 2013, s. 57-58.

${ }^{80}$ M. Stolleis, Le Saint Empire Romain de Nation Allemande, Le Reich Allemand et la Troisième Reich, „Francia” 2007, t. 34, nr 3, s. 23.

${ }^{81}$ Zob. np. J. Zielonka, Europa jako imperium. Nowe spojrzenie na Unię Europejska, Warszawa 2007; U. Beck, E. Grande, Europa kosmopolityczna. Społeczeństwo i polityka w drugiej nowoczesności, Warszawa 2009, s. 97-164.

82 H.A. Oberman, Marcin Luter. Człowiek między Bogiem a diabłem, Gdańsk 1996, s. 22-23.

83 B. Lohse, Martin Luther. Eine Einführung in sein Leben und sein Werk, München 1981, s. 79. 
pominięto kwestię jego odmowy podobnego posłuszeństwa książąt Rzeszy wobec cesarza $^{84}$. Luter przekształcił spór kompetencyjny suzerena $\mathrm{z}$ wasalami wewnątrz Rzeszy w konflikt pomiędzy suwerennymi państwami, a późniejsi badacze - podświadomie rzutując ustalenia pokoju westfalskiego (1648) na sytuację polityczną w Sacrum Imperium w XVI w. - przyjęli tutaj jego punkt widzenia. W ten sposób ugruntowało się współczesne przekonanie, że od początku mamy do czynienia z konfliktem pomiędzy państwami o zakres ich niezależności (w kwestii konfesyjnej) od imperatora ${ }^{85}$.

Program luterańskich książąt i wolnych miast był stosunkowo prosty: każde z nich powinno być uznane za suwerenny podmiot stosunków międzynarodowych, przy okazji posiadający prawo wyboru swojej konfesji, stanowiącej coś w rodzaju współczesnej oficjalnej ideologii państwowej. Uprawnienia cesarza powinny być symboliczne i sprowadzać się do zwoływania Sejmu Rzeszy. Postanowienia tegoż powinny zaś obowiązywać tylko te państwa, których delegaci je poparli. W praktyce był to program dezintegracji imperium bez otwartego ogłoszenia tego faktu ${ }^{86}$.

Program strony cesarskiej także nie był skomplikowany. Karol V Habsburg, jako ostatni imperator w dziejach, dążył do zjednoczenia całego świata chrześcijańskiego pod swoim berłem, co nie udało mu się ze względu na zbrojny opór Szwecji, Francji i książąt protestanckich w Rzeszy. Dla historyków nie jest jasne, czy jego program opierał się na chęci stworzenia unitarnego państwa światowego, czy na (mocno już archaicznych) zasadach lennych ${ }^{87}$, dlatego nie mogę go jednoznacznie przedstawić w kontekście cesarskiego programu konstytucji Sacrum Imperium, acz zdecydowanie opowiadam się za tym drugim poglądem. Program następnych Habsburgów jest już łatwiejszy do przedstawienia, ponieważ głosili ideę zjednoczenia Rzeszy pod swoim berłem, za wyraz posłuszeństwa książąt i wolnych miast uznając likwidację protestantyzmu. Oznaczało to chęć przekształcenia Cesarstwa $\mathrm{w}$ federację, $\mathrm{z}$ bezpośrednim panowaniem imperialnym $\mathrm{w}$ kwestiach doktrynalnych, co wymagało spacyfikowania proluterańskich stanów. Nie jest przypadkiem, że wokół wiedeńskiego dworu zgromadzili się pierwsi intelektualiści piszący o Niem-

${ }^{84}$ Wyjątki to: K.-F. Stolzenau, Die Frage des Widerstandes gegen die Obrigkeit bei Luther zugleich in ihrer Bedeutung für die Gegenwart [w:] G. Wolf (red.), Luther und die Obrigkeit, Darmstadt 1972, s. 241-272; E. Weimar, Martin Luther: Obrigkeit, Gehorsam und Widerstand [w:] G. Wolf (red.), Luther und die Obrigkeit, s. 320-334.

${ }^{85}$ A. Wielomski, Martin Luter wobec Sacrum Imperium, „Dialogi Polityczne” 2019, nr 27, s. $29-41$.

${ }^{86}$ R.G. Asch, The Thirty Years War. The Holy Roman Empire and Europe, 1618-1648, New York 1997, s. 17-21; R. von Friedeburg, Luther's legacy: the Thirsty Years War and the modern notion of 'state' in the empire, 1530s to 1790s, Cambridge 2017, s. 90-96.

${ }^{87}$ R. Menéndez Pidal, Idea Imperial de Carlos V, Madrid 1971, s. $20-21$ (teza o zjednoczeniu świata na zasadach lennych); J.L. Villacañas, Qué impero? Un ensayo polémico sobre Carlos V, Madrid 2008, s. 15-25 (teza o państwie unitarnym uniwersalnym). 
cach jako o jednym narodzie i o cesarzu jako przywódcy tego zjednoczonego narodu ${ }^{88}$.

Traktat westfalski, kończący wojnę trzydziestoletnią (1618-1648) między Habsburgami i książętami, określał Rzeszę mianem Konfederacji Germańskiej $\mathrm{i}$, „systemu federatywnego" ${ }^{89}$. Często pisze się, że traktat ten ukształtował suwerenne nowoczesne państwa ${ }^{90}$. Jest to pogląd prawdziwy, choć jedynie odnośnie do Rzeszy (Francja, Anglia, Hiszpania, Rzeczypospolita były państwami suwerennymi już od dawna). Na jego mocy Cesarstwo zostało zredukowane do pustych tytułów honorowych, za którymi nie szła żadna polityczna treść. Traktaty wyliczają starannie uprawnienia księstw (ale nie uprawnienia cesarskie), jednak nie pozwalają poszczególnym władcom ogłosić wyjścia z samego Cesarstwa, co teoretycznie dawało imperatorowi jakąś formę zwierzchności nad nimi. Równocześnie księstwa uzyskały prawo do zawierania traktatów międzynarodowych i zagwarantowano im suwerenność wewnętrzną, ale cesarzowi pozwolono reprezentować na zewnątrz całe Cesarstwo. Został także gwarantem istnienia i niepodległości poszczególnych księstewe $\mathrm{k}^{91}$. W dodatku minisuwereni nie zostali dopuszczeni do podpisania samego traktatu, który podpisały tylko państwa w pełni suwerenne: Francja, Szwecja i cesarz w imieniu swoich posiadłości. Pozostałe kraje dopisały się zaś poniżej ${ }^{92}$.

Badacze uważają, że traktaty te przekształciły Rzeszę w „konfederację państw"93, przy czym ogólne i niesprecyzowane zapisy o cesarzu jako zwierzchniku i reprezentancie Sacrum Imperium w sprzyjających warunkach mogłyby być użyte do podważenia suwerenności książąt. Cesarz nigdy nie miał jednak mieć już przewagi militarnej. Dlatego zabrany Cesarstwu zakres suwerenności przejęły suwerenne państwa terytorialne, które teraz przekształciły się zwykle w małe i maleńkie despotie, pozbawione reprezentacji stanowej i praw fundamentalnych. Miarą nieograniczonej władzy lokalnych suwerenów protestanckich było zjawisko konfesjonalizacji, czyli prawa każdego z nich do narzucenia swoim poddanym określonej konfesji, zmuszenia ich do jej przyjęcia i uczestniczenia w nakazanych praktykach religijnych. Oznaczało to całkowitą podległość stanów suwerenowi. W państewkach protestanckich partykularna konfesja uchodziła za przejaw lojal-

${ }^{88}$ C. Hirschi, Wettkampf der Nationen. Konstruktionen einer deutschen Ehrgemeinschaft an der Wende von Mittelalter zur Neuzeit, Göttingen 2005, s. 251-380.

${ }^{89}$ V.R. Castro Gómez, Pensado la nación..., s. 107.

90 I. Popiuk-Rysińska, Suwerenność w rozwoju stosunków międzynarodowych, Warszawa 1993, s. 48; O. Dann, Nation und Nationalismus in Deutschland 1770-1990, München 1996, s. 43-44; J. Bartelson, A Genealogy of Sovereignty, Cambridge 1996, s. 138.

${ }^{91}$ K. Maletke, Les relations entre la France et le Saint-Empire au XVIIe siècle, Paris 2001, s. 33-39; G. Braun, La connaissance du Saint-Empire en France du Baroque aux Lumières, München 2010, s. 49-51.

92 G. Braun, La connaissance du Saint-Empire..., s. 58.

${ }_{93}$ K. Maletke, Les relations entre la France..., s. 34. 
ności wobec suwerena. Innowiercy byli traktowani jako wrogowie państwa, a samo innowierstwo często było penalizowane. Lokalni władcy powoływali biskupów, a niekiedy także niższych duchownych ${ }^{94}$. Odpowiedzią na to zjawisko protestanckie była podobna w założeniach konfesjonalizacja katolicka, z tą różnicą, że suwereni nie powoływali bezpośrednio biskupów, lecz wnioskowali do władz kościelnych o ich powołanie ${ }^{95}$.

Obserwatorzy z epoki pisali o postwestfalskim Cesarstwie jako o „państwie nieregularnym" i ,podobnym do monstrum" ${ }^{\circ}$. W Encyklopedii Diderota (Encyclopédie ou Dictionnaire raisoné des sciences, des arts et des métiers, 1751-1766) pod hasłem „Niemcy” czytamy, że jest to „zbiór wielkiej ilości wolnych i suwerennych państw mających wspólną głowę"97. Niemcy przestali być na stulecia narodem, Sacrum Imperium przestało być państwem, cesarz utracił miraż władzy uniwersalnej, a tradycyjny ustrój i prawa fundamentalne ustąpiły terytorialnemu absolutyzmowi poszczególnych władców, rozciągającemu się nawet na kwestie sumienia poddanych.

\section{3. ŚMIERĆ IDEI PRAW FUNDAMENTALNYCH}

Nastąpił zatem kompletny rozkład praw fundamentalnych i tradycyjnego europejskiego konstytucjonalizmu. Znamionuje go kilka dat: pokój westfalski w Cesarstwie (1648); wybuch rewolucji angielskiej (1642), ścięcie Karola I Stuarta (1649) i rewolucja chwalebna (1688) w Anglii; pokój w Utrechcie i złamanie prawa salickiego w kwestii dziedziczenia tronu (1713) oraz edykt o sukcesji Ludwika XIV (1714) we Francji. Dlatego można uogólnić tezę, że tradycyjny konstytucjonalizm upadł między połową XVII a początkiem XVIII w.

Oczywiście były i wyjątki od zasady powszechnej. W Rzeczypospolitej tradycyjne zasady konstytucyjne potwierdzono jeszcze w prawach kardynalnych (1768), które należy uznać za pierwszą spisaną konstytucję w polskich dziejach, opartą na tradycyjnym i ewolucyjnie rozwijającym się konstytucjonalizmie, acz stopniowo prowadzącym do upadku państwa. Została ona obalona dopiero w 1791 r. przez

${ }^{94}$ J. Sieglerschmidt, Territorialstaat und Kirchenregiment. Studien zur Rechtsdogmatik des Kirchenpatronatsrechts im 15. und 16. Jahrhundert, Köln 1987, s. 223-276; H.R. Schmidt, Konfessionalisierung im 16. Jahrhundert, Münich 1992, s. 44-66.

${ }^{95}$ E.W. Zeeden: Grundlagen und Wege der Konfessionsbildung in Deutschland im Zeitalter der Glaubenskämpfe, „Historische Zeitschrift” 1958, nr 185, s. 249-299; W. Reinhard, Was ist katholische Konfessionalisierung [w:] idem, H. Schilling, Die katholische Konfessionalisierung, Münster 1995, s. 419-452.

${ }_{96}$ M. Stolleis, Le Saint Empire..., s. 23.

${ }^{97}$ D. Diderot, Allemagne [w:] Encyclopédie ou Dictionnaire raisoné des sciences, des arts et des métiers, t. I, Neufchastel 1751-1766, s. 281. 
zamach stanu - tak to wówczas odbierano - na Sejmie Wielkim i uchwalenie Konstytucji 3 Maja. W Hiszpanii tradycyjna konstytucja utrzymała się aż do wojny o sukcesję hiszpańską, gdy zaczęli panować Bourboni (1713), którzy stopniowo rozmontowywali system tradycyjnej konstytucji i praw fundamentalnych. Badacze hiszpańscy twierdzą, że do końca rządów Habsburgów mówiono i pisano, iż władcy administrują, posiadają ,zarząd” (gobierno) nad wspólnotą polityczną, a dopiero od nadejścia Burbonów mamy „państwo” (Estado), czyli byt nowożytny, kreujący rzeczywistość polityczno-społeczną ${ }^{98}$. Dlatego przez cały XVII wiek na Zachodzie Europy tylko w Hiszpanii swobodnie pisano kolejne traktaty o prawie stanów do buntu wobec władcy-tyrana, z których najważniejszy, autorstwa Juana de Mariany, W skrajnych przypadkach pozwalał na prywatne tyranobójstwo ${ }^{99}$. W tym samym czasie we Francji potępiano i palono dzieła myślicieli mniej radykalnych (jak Roberto Bellarmino), dopuszczających prawo do jakiegokolwiek oporu ${ }^{100}$.

Prawa fundamentalne i tradycyjny konstytucjonalizm upadły pod ciągłym naciskiem na wzmocnienie państwa, wywołanym przez śmiertelny konflikt reformacji z kontrreformacją, krajów protestanckich z katolickimi. Były to nie tylko wojny międzypaństwowe, lecz także szereg wojen domowych. Ich efektem było pojawienie się kategorii racji stanu i popularyzacja makiawelizmu politycznego. Po rozpadzie Christianitas państwa narodowe i terytorialne zostały zmuszone do mobilizacji wszelkich zasobów ekonomicznych i demograficznych, aby wystawiać coraz liczniejsze armie przeciwko heretykom wewnątrz i innowierczym armiom na zewnątrz. Prawa fundamentalne, tradycyjne konstytucje, uprawnienia stanowe i korporacyjne chroniły ludzi przed tą mobilizacją wszystkich i wszystkiego. Dlatego musiały zostać najpierw naruszone, a potem ostatecznie zlikwidowane, jako bariery ograniczające siłę sprawczą suwerenów, którzy kierując sprawami politycznymi, walczyli o przetrwanie swoich państw w dżungli stosunków międzynarodowych po $1517 \mathrm{r}$.

Myślicielem, który przedefiniował pojęcie praw fundamentalnych, był Thomas Hobbes. W 26 rozdziale Lewiatana (1651) filozof ten pisze:

Fundamentalnym bowiem w każdym państwie jest to prawo, które, gdy zostanie usunięte, to państwo traci swe podstawy i zostaje całkowicie zrujnowane, na podobieństwo budynku, w którym zniszczono fundamenty. Fundamentalne więc jest to prawo, które zobowiązuje poddanych do podtrzymywania wszelkiej mocy danej

${ }^{9}$ D. Negro, Sobre el Estado en España, Madrid 2007, s. 4. Parę pojęć gobierno vs Estado autor ten thumaczy dokładniej w pracy Gobierno y Estado, Madrid 2002, s. 33-40.

99 J. de Mariana, Del Rey y de la institución real [De rege et regis institutione, 1599] [w:] idem, Obras, t. II, Madrid 1854, ks. I, rozdz. 6-7, s. 479-485.

100 Zob. np. Extrait des registres du Parlament de Paris. Contre le livre intitulé 'Tractatus de potestate Summi Pontificis in rebus temporalibus adversus Gulielmum Barclaium', auctore Robert Sancte Ecclesia Romanae Cardinali Bellarmin, Paris 1610. 
suwerenowi, czy to monarsze, czy zgromadzeniu suwerennemu, bez której państwo nie może istnieć; takiej na przykład, jak moc wojny i pokoju, sądzenia, doboru urzędników i czynienia wszystkiego, co suweren będzie uważał za niezbędne dla dobra publicznego. Nie jest zaś prawem fundamentalnym to, którego odwołanie nie pociąga za sobą rozwiązania państwa ${ }^{101}$.

Podobną tezę kilkanaście lat później znajdujemy w Hobbesowskim Behemocie (Behemoth, 1668): „Czym są prawa fundamentalne? [...] Król nie zna innych praw fundamentalnych niż »Salus Populus«, czyli bezpieczeństwo i dobrobyt swojego ludu"102 . Równocześnie Hobbes podważa tradycyjny konstytucjonalizm, wywodząc władzę suwerenną a to z osławionej koncepcji umowy społecznej i pierwotnej suwerenności ludu, a to z kalwińsko odczytywanej litery Starego Testamentu, jako odwzorowanie władzy królów izraelskich, która pochodziła z bezpośredniego bożego ustanowienia i nie ograniczały jej żadne prawa tradycyjne ${ }^{103}$.

Tym samym tropem we Francji poszedł bp Jacques Bossuet, który w Polityce wysnutej z Pisma Świętego (Politique tirée de l'Ecriture Sainte, 1679, wydane 1709) także widzi władzę królewską jako refleks królów izraelskich oraz - o czym rzadko się pamięta - wywodzi ją z pierwotnego stanu chaosu i pewnego rodzaju kontraktu, na mocy którego ludzie przekazali suwerenowi wszelkie prawa, nie ograniczając ich żadnymi prawami fundamentalnymi ${ }^{104}$. Dla Hobbesa i Bossueta jest już tylko jedno polityczne prawo fundamentalne: samozachowanie państwa, będące fundamentem wszelkich innych praw poddanych, wspaniałomyślnie danych im ewentualnie przez suwerena. Teza ta została niezależnie sformułowana w ich pismach między 1651 a 1679 r. Dlatego Monteskiusz w swoim Duchu praw (1748), mając przed oczami monarchię francuską i wzorujące się na niej państwa europejskie (absolutyzmy oświecone), uważa, że o ile zasadą prawdziwego rządu monarchicznego jest honor, o tyle zasadą despotycznych monarchii już tylko strach ${ }^{105}$. Władcy w jego epoce nie ograniczają już jakiekolwiek prawa fundamentalne czy zasady konstytucyjne, a stopniowo też honor własny, czyli poczucie, że pewnych rzeczy robić nie wypada, ani honor szlachty, która nie chce zgiąć się przed orientalnym despotyzmem. Monarchia zmienia się w despotyzm.

Z wyjątkiem Anglii wszystkie państwa w XVIII w., zachwycone potęgą Francji Ludwika XIV, poszły w kierunku absolutyzmu oświeconego, gdzie rzeczywiście już tylko honor mógł ograniczyć wszechwładzę monarszą. Suweren jest dżentelmenem,

101 T. Hobbes, Lewiatan, czyli Materia, forma i władza państwa kościelnego i świeckiego, tłum.

Cz. Znamierowski, t. II, Warszawa 1954 [1651], rozdz. 26, s. 256-257.

102 T. Hobbes, Behemoth [1668] [w:] idem, Tracts, t. II, London 1682, s. 112.

103 T. Hobbes, Lewiatan..., t. III, rozdz. 40, s. 418-430.

104 J. Bossuet, Politique tirée de l'Ecriture Sainte, Paris 1828 [1709], ks. II, rozdz. 1, 4, s. 6668 (element kontraktualny); ks. III, rozdz. 2, 1-3, s. 85-90 (refleks królów starotestamentowych).

105 Monteskiusz, O duchu praw, Kęty 1997 [1748], ks. III, rozdz. 6-8, s. 31-32. 
więc nawet jeśli wolno mu uczynić wszystko, to nie wszystko robić wypada, choć bojący się go poddani i tak nie śmią już protestować...

\author{
THE BIRTH, DEVELOPMENT, AND DISINTEGRATION OF THE IDEA \\ OF FUNDAMENTAL LAWS AND OF A TRADITIONAL CONSTITUTION \\ IN THE WESTERN POLITICAL THOUGHT \\ FROM THE RENAISSANCE TO THE AGE OF ENLIGHTENMENT
}

\begin{abstract}
The paper presents the idea of fundamental laws and of a traditional constitution in the European practice and political thought between the $16^{\text {th }}$ and the 17 th century. The article demonstrates that the essence of this concept is the limitation of a sovereign's power by a parliament, the rights of social estates, religion and traditional institutions. The source of the disintegration and of the collapse of this first wave of European constitutionalism can be found in the Protestant Reformation, domestic and foreign religious wars as well as in the methods employed in confessional wars: Machiavellianism and political mobilisation.
\end{abstract}

Keywords: fundamental laws, constitution, Renaissance, Reformation, Baroque 